\title{
STUDY THE INFLUENCE OF LATERAL SHOOT REMOVAL AND FOLIAR APPLICATION OF ALGAMIX ON VEGETATIVE GROWTH AND YIELD OF GRAPEVINE (VITIS VINIFERA L.) CV. ZARK
}

\author{
Hussein M. Suliman Nerway \\ Dept. of Horticulture, College of Agricultural engineering sciences, University of Duhok, \\ Kurdistan Region-Iraq
}

(Received: March 4, 2020; Accepted for Publication: August 24, 2020)

\begin{abstract}
A field experiment was carried out in a private orchard located at Dargalle village, Duhok governorate, Kurdistan region, Iraq, during growing season of 2019 to investigate the effect of lateral shoots removal, spraying of three concentrations $\left(0,4\right.$ and $\left.8 \mathrm{ml} \mathrm{L}^{-1}\right)$ of Algamix and their interaction on growth, yield and quality of ' Zark' grapes. The results indicated that lateral shoot removal and both concentration of Algamix significantly increased leaf area and shoot length, as soon as TSS and total yield per vine. The interaction between the studies factors varied in their effect on the traits, the most important interaction was the interaction of lateral shoot removal + spraying of high concentration of Algamix $\left(8 \mathrm{ml} . \mathrm{L}^{-1}\right)$.
\end{abstract}

KEY WORD: lateral, shoot, Algamix, grape, Zark.

\section{INTRODUCTION}

G rape is the most preferential, high nutritional value fruit crops in the world (Gawadshahen, et al., 2012). It has a delicious taste and a good source of sugar, acids, minerals, vitamins and tannins with a sweet flavor (Isbat, M.and N. Zeba, 2011). Grapes are adapted to a wide range of climates and they have been distributed in the tropics, subtropics and the temperate regions (Creasy \& creasy, 2009). There are more than 100 cultivars grown in Iraq now, generally they are seeded cultivars and few cultivars are seedless, most of these cultivars are grown in Kurdistan Region (Al-Rawi, 2005; Alsaidi, 2014 and AL-Atrushy, 2018).

Zark is the most widely planted variety in Dohuk, where it is planted in rain-fed areas. There are several villages which specialize in its cultivation including Besefki, Darkechnik, Swaratuka, Ashawi and Dargale, this variety ripens at the second week of August. It is suitable for fresh consumption, juice, wine and raisin production. The berries are round and compact with a white-yellow color. The pulp is fleshy and juicy. The skin is somewhat thick with a touch of tannin, which decreases when the fruits are fully ripened. The TSS was about 16\%. The inflorescence of this variety is hermaphroditic and it is a good pollinator for the pistillate varieties. This variety is recognized by its high (heavy) productivity and its response to short spur pruning (USIAD, 2005).

Lateral shoot removal is to achieve a balance between vegetative growth and crop levels and to achieve maximum interception of light. While avoiding excessive canopy growth that can shade grape clusters and interior leaves, leading to poor quality grapes and fruitful buds. Leaving too much crop on a grapevine delays maturity, limits vegetative growth, and can lead to reduction in vine size and death of the vine. Leaving too little crop can lead to excessive shoot growth, canopy shading and lower return crop, because shaded buds are less fruitful than buds exposed to sunlight. The overall goal is to achieve an adequate ratio of leaf area to crop level (Hellmann 2004).

The excess shoot vigor may be detrimental because most of the metabolites are utilized for continuous vegetative growth. Therefore, it is necessary to reduce the excess vigor of vegetative growth without reducing the shoot number of the vine, which can be achieved with the application of growth retardants like Cycocel. Cycocel plays 
an important role in reducing the excess vigor in grapes (Smirnov, 1988, Shikhamany and Reddy, 1989; Ramteke and. Somkumar, 2005).

Hunter (2000) investigated the effect of combinations of shoot positioning, topping, leaf removal and shoot removal treatments on yield and growth compensation of a vertically trellised Vitis vinifera $\mathrm{L}$. cv. Sauvignon were spaced $2.75 \mathrm{x}$ $1.5 \mathrm{~m}$. Significant compensatory growth and yield was induced by the removal of lateral shoots.

AL-ATRUSHY (2016) found that the cluster weight, TSS and total sugars percentage were significantly increased by removing of lateral shoots of grapevine cv. Taifi compared to unremoved.

Cassan et al., (1992) stated that in nature, Seaweed extract (Algamix) measured as a vital source of nutrition. Seaweed extracts are a good source of trace elements to improve marginal deficiencies (Aitken \&Senn, 1965; Khan, et al., 2012), also, it contains various trace elements, vitamins, amino acids and plant growth hormones (Indole acetic acid, Indole Butyric acid \& Cytokinin's) that have promotive effects on the growth and development of plant (Metting et al., 1990; Spinelli et al., 2009; Abdel-Mawgoud et al., 2013). Birjely (2011) investigated the effect of foliar application of Urea, Ascorbic acid and Seaweed extract on Vegetative growth, Yield and its components and Chemical characteristics of berries, of the European grape (Vitis vinifera L.) cv. Rash-Mew. Results indicated that foliar spray of seaweed extract at $15 \mathrm{ml} . \mathrm{L}^{-1}$ had significant increases in all vegetative growth, yield and its components and chemical characteristics of berries.

Mustafa (2016) studied the effect of different concentration of algamix $\left(0,2\right.$ and $\left.4 \mathrm{ml}^{-1}{ }^{-1}\right)$ and Ascorbic acid (0, 0.75 and 1.5 g. $\left.^{-1}\right)$ on yield, berries quality and chemical characteristics of berries of 19 years old grapevine cv. Bae-Dank. Foliar application of Algamix significantly increased number of cluster, cluster weight, No. of berries per cluster, yield, berry length and diameter, weight and size of 100 berries, as well as TSS, juice and total sugar percentage and juice density. Whereas same treatment significantly reduced total acidity percentage in grape juice.

Consequently, this experiment was carried out to investigating the effect of lateral shoot removal and foliar application of Algamix and their interaction on the vegetative growth and yield on grapevine cv. Zark and their combination on grapevine cv. Zark, to improve the yield and fruit quality.

\section{MATERIAL AND METHOD}

This study was instigated on the private orchard in Dargalle village near Zawita, Duhok governorate during growing season of 2018-2019 to investigate the effect of lateral shoot removal and foliar application of Algamix on the vegetative growth and yield of grapevine cv. Zark (Vitis vinifera L.), two levels of shoot removal carried out (non-removal and $100 \%$ removal), In addition to foliar application of Algamix at three concentrations $\left(0,4\right.$ and $8 \mathrm{ml}$. L $\left.\mathrm{L}^{-1}\right)$. So the treatments consisted of two levels of lateral shoot removal and three concentrations of Algamix. Spraying of Algamix was done twice per season; first two weeks after growth began, second two weeks after berry setting.

The selected 'vines must be uniform in vigor; it was 17-year-old planted in clay soil spaced at $2.5 \times 2.5 \mathrm{~m}$, the vines were trained of head training system. Winter pruning was established at the second week of March. Vine load was sixteen buds (four fruiting spars by four buds).

A (RCBD) was followed in the experimental every treatment was done on the same vines.

the powder detergent used as wetting agent at (1-2 g.L- $\left.{ }^{1}\right)$ added to all the spraying solution including control. The vines were sprayed with Algamix solutions till run off. Horticultural practices except the addition of sulfur were used as usual. The measurements were calculated consist of leaf area, shoots length, leaf dry weight, chlorophyll content, TSS, clusters number per vine, clusters weight and total yield per vine.

\section{RESULTS AND DESCUSION}

\section{1- Vegetative growth:}

It's cleared from data presented in table (1) that removing lateral shoots significantly increased leaf area, the highest leaf area (158.12) obtained from removing lateral shoots as compared to the lowest leaf area (141.68) from non- removing lateral shoots. Also removing lateral shoots significantly increased shoot length, the highest shoot length (1.85) obtained from removing lateral shoots as compared to the lowest shoot length (1.48) from 
non-removing lateral shoots. Whereas removing of lateral shoots had no significant effect on leaf dry total chlorophyll content and weight for the same table also shows that foliar spraying of Algamix increased leaf area, shoot length and total chlorophyll content, the maximum values (167.03, 1.84 and 56.05) where resulted from vine sprayed with high concentration of Algamix $\left(8 \mathrm{ml} . \mathrm{L}^{-1}\right.$ respectively while spraying of Algamix had no effect on leaf dry weight.

For the interaction, it's cleared from the table (1) that the highest values (169.52, 1.97 and 58.86) leaf area, shoot length and chlorophyll content respectively were obtained from the interaction of lateral shoot removal $+8 \mathrm{ml}$. $\mathrm{L}^{-1}$ Algamix), while removing of lateral shoots + spraying of ${ }^{-}$Algamix had no effect on the leaf dry weight.

Table (1):- Effect of lateral shoot removal and foliar application of Algamix on vegetative growth parameters of grapevine cv. Zark.

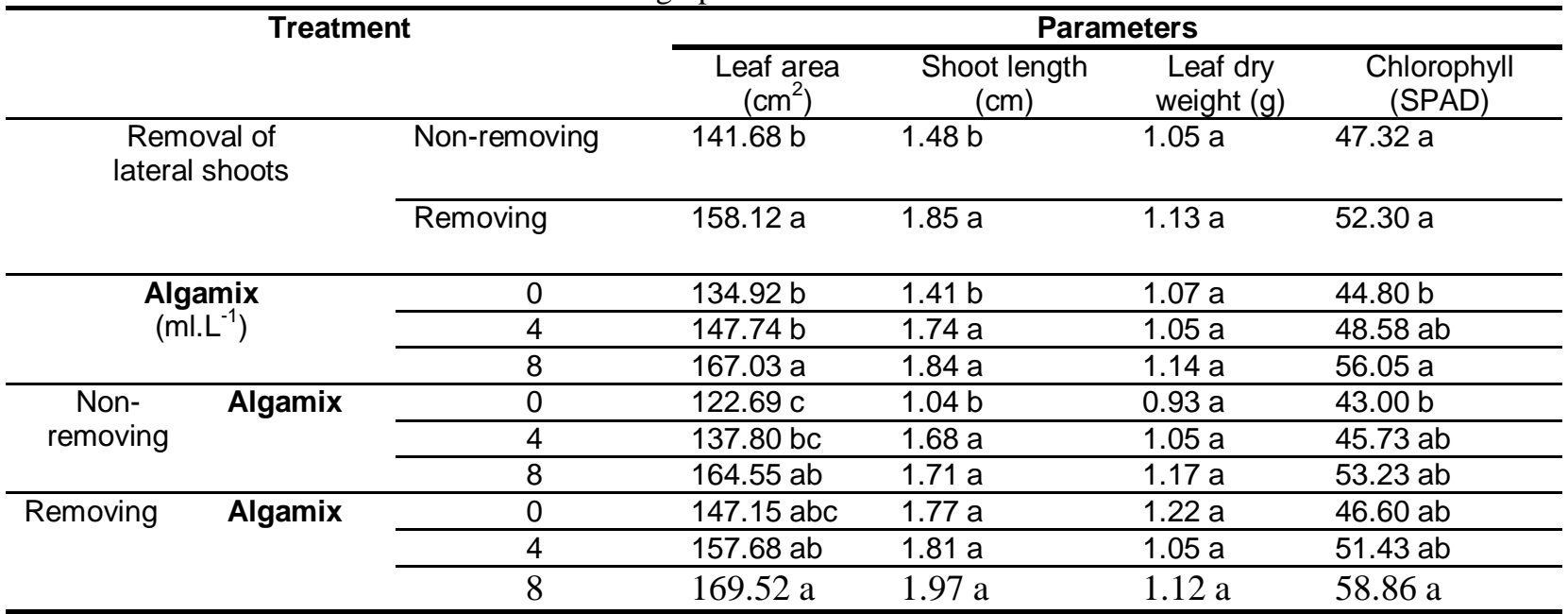

Means with the same letter are not significantly different according to Duncan multiple ranges test at 5\% level.

\section{2- Yield and its components:}

Table (2) showed that removing lateral shoot significantly increased TSS and total yield per vine, the highest values (21.67 and 6.33) resulted from removing lateral shoots as compared from the lowest TSS and total yield (18.22 and 4.50) respectively from non-removing lateral shoots. Whereas removing lateral shoot had no significant effect on cluster number and cluster weight. Also table (2) cleared that foliar application of Algamix significant increased TSS and total yield the maximum values (21.83 and 6.54) where resulted from vine sprayed with high concentration of
Algamix (8ml. $\left.\mathrm{L}^{-1}\right)$ respectively. While foliar spraying of Algamix had no visible effect on weight of cluster and their number.

For the interaction, it's showed from table (2) that the highest values (24.00 and 7. 36) of TSS and total yield respectively were obtained from the interaction between lateral shoot removal and spray $8 \mathrm{ml} .1^{-1}$ Algamix as compared with nonremoving lateral shoots $\left(4 \mathrm{ml} . \mathrm{l}^{-1}\right.$ Algamix and control) while removing of lateral shoot + spraying of $8 \mathrm{ml}^{-1} \mathrm{l}^{-1}$ Algamix had no effect on cluster number and cluster weight. 
Journal of University of Duhok., Vol. 23, No.2 (Agri. and Vet. Sciences), Pp 13-19, 2020

Table (2):- Effect of lateral shoot removal and foliar application of Algamix on yield quantities and qualities parameters of grape cv. Zark.

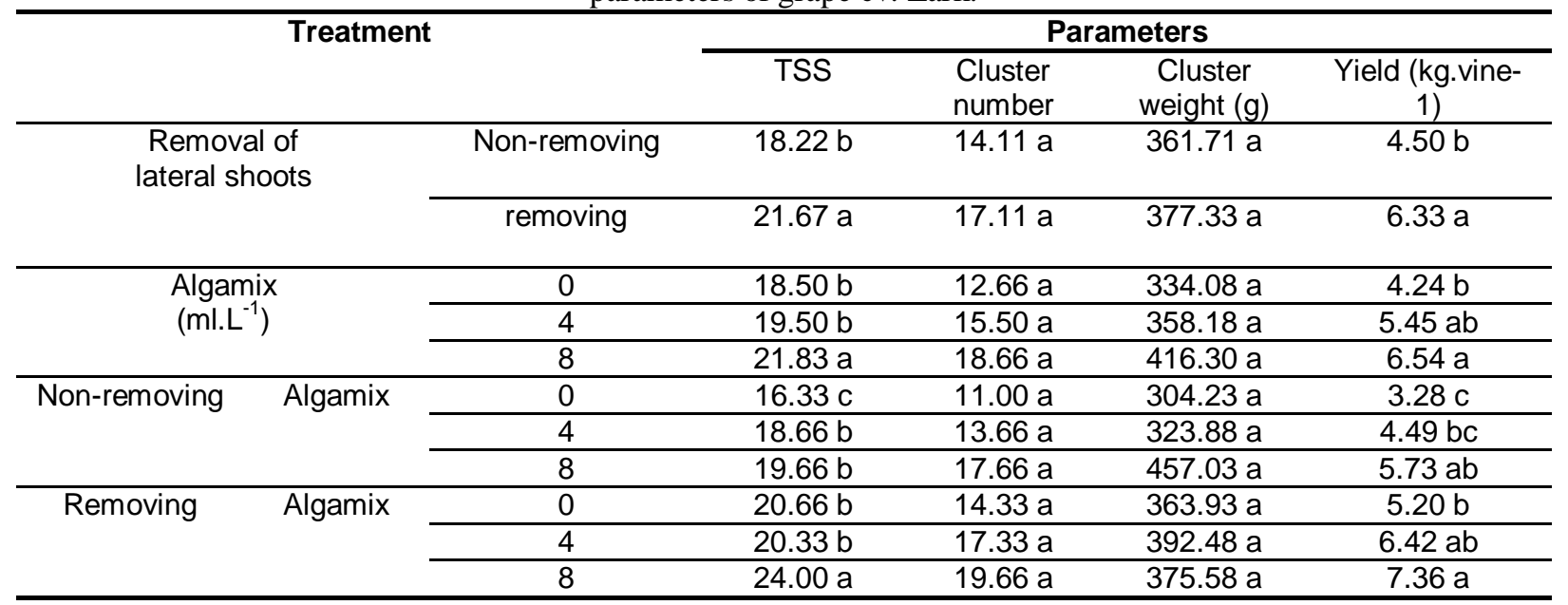

Means with the same letter are not significantly different according to Duncan multiple ranges test at $5 \%$ level.

It is clear from table 1- 2 that removing of lateral shoots significantly increased leaf area and shoot length as well as Yield, number and weight of clusters and TSS percentage, This increasing may attributed to that lateral shoot correctly invested assimilates in the expansion of the assimilating surface (Candolfi-Vasconcelos and Castagnoli, 2006). The increase in a shoot length, leaf area and chlorophylls could be due to a sufficient accumulation of reserves required for the growth of these leaves (Candolfi-Vasconcelos and Koblet, 1990), additionally this overtopping could be attributed to the increasing of leaf surface of main shoot (Candolfi-Vasconcelos and Castagnoli 2001), furthermore making remaining leaves more active photo-synthetically (Hunter and Visser 1989) contributing to the increase of the leaf area and chlorophyll content of the main shoots (Candolfi-Vasconcelos and Castagnoli 2001).

The foliar spray of Algamix, had a positive effect on must parameters, since spraying grapevine with $8 \mathrm{ml} . \mathrm{L}^{-1} \quad$ Algamix significantly increased must vegetative growth, yield and its components represented in clusters characteristics and berries physical and chemical qualities, this effect may be due to the role of macro and micronutrient (the main content of Algamix) in stimulating growth characters (Kulk, 1995) and their role in an improving the nutrient uptake by root (Crouch, et al., 1990), and increasing vegetative growth parameters due to increasing N, $\mathrm{P}$ and $\mathrm{K} \%$ in the leaves (Mancuso et al., 2006) and their role in activating the cell division and increasing biosynthesis of organic products that lead to accumulation of carbohydrates and protein in clusters and berries and increasing cell respiration, photosynthesis and various enzymes reaction (Turan and Kose 2004; Vernieri et al., 2005).

\section{4- REFERENCES}

Abdel-Mawgoud, A.M. R.;Tantaway,A.S. M.; Hafez,M. M.M. and A. M. SAbdulrahman(2013).Effect of foliar spray of ascorbic acid, zinc, seaweed extracts and biofertilizer (em1) on growth of almonds (Prunusamygdalus) Seedling.Int. J. Pure Appl. Sci. Technol. 17(2): pp. 62-71.

Aitken, J. B. and T. L. Senn (1965). Seaweed products as a fertilizer and soil conditioner. Botanica Marina 8. P: 144.

Al-Atrushy, Sh. M. (2018). Grape production. Unvi. of Duhok press. Ministry of High Education and Scientific Research. Kurdistan region. Iraq.

Al-Atrushy, Sh. M.(2016). Effect of tipping, lateral shoots removal and spraying of cycocel on growth, yield and quality of grapevine (vitis vinifera 1.) cv. Taifi. Journal of University of Duhok., Vol.19, No.1 (Agri. and Vet.Sciences),Pp 403-410, 2016 (Special Issue). 
Al-Rawi, W. A. (2005). Characteristics of F1 hybrid grape produced from crossing between AlAbbasi and Thompson Seedless cultivars which grafted on three European grapes rootstocks. $\mathrm{PhD}$. Thesis. Coll. Agric. Univ. Baghdad.

Alsaidi, I. H. (2014). Grape Classification. Dar AlWathah Publisher, Jordan.

Birjely, H. M (2011). Effect of foliar application of urea, ascorbic acid and seaweed extract on vegetative growth, productivity and quality of grape (Vitisvinifera L.) cv. rash-mew under nonirrigated conditions. Msc. Thesis, College of Agriculture and Forestry.University of Duhok. Iraq.

Candolfi-vasconcelos, M. C. and S. Castagnoli (2001). Leaf canopy structure and vine performance. Am. J. Enol. Vitic. 51(4): 1-14.

Candolfi-Vasconcelos, M. C. and W. Koblet (1990). Yield fruit quality, bud fertility and starch reserves of the wood as a function of leaf removal in Vitis vinifera. Evidence of compensation and stress recovering. Vitis 29: 199-221.

Candolfi-Vasconcelos, M. C. C. and S. Castagnoli (2006). Effect of canopy management practices on fruit set, yield components and fruit composition. Dep. of Hort., Oregon State University.

Cassan, L.; Jean, I.; Lamaze,J. and J.F. Morotgaudry (1992). The effect of the Ascophylumnodosum extractGeomer GA14 on the growth of spinach. Bot. Mar., 35: 437-439.

Creasy, G.L. and L.L. Creasy. 2009. Grapes. Oxfordshire, UK: CABI. British Library, London, UK.

Crouch, I. J.; Beckett, R. P. and Vanstaden, J. (1990). Effect of seaweed concentrate of the growth and mineral nutrition of nutrient stressed Lettuce. J. Appl. Phycology. 2, 269-272.
GawadShaheen, M.A.; Abdel-Wahab, S. M.; Hassan, E. A. and A. M. R. A. AbdelAziz (2012). Effect of some soil conditioners and organic fertilizers onvegetative growth and quality of crimson seedless grapevines.J. of Hort. Sci.\& Ornamental Plants 4 (3): 260-266.

Hellmann, E. (2004). Canopy management. Texas coop. Ext. Texas univ. p: 1-4.

Hunter, J. and H. J. Visser (1989). The effect of partial defoliation, leaf position and developmental stage of the vine on the photosynthetic activity of (Vitis vinifera L.) Cabernet sauvignon. S. Afr. J. Enol. Vitic. 9:9-15.

Hunter, J. J. (2000). Implications of Seasonal Canopy Management and Growth Compensation in Grapevine. ARC Infruitec-Nietvoorbij, Private Bag X5026, 7599 Stellenbosch, South Africa.

Isbat' M.and N. Zeba (2011). Quality and shelf life evaluation of two grape varieties in different agro-ecological zones of Bangladesh. J. Expt. Biosci. 2(2):89-96.

Khan, A.S.; Ahmad,B.;Jaskani,M.J.; Ahmad, R. and A. U. Malik (2012). Foliar application of mixture of amino acids and seaweed(Ascophylumnodosum) extract improve growth and physico-chemical properties of grapes. Int. J. Agric. Biol., 14: 383-388.

Kulk, M. M., (1995). The potential for using cyano bacteria (blue- green- algae) and algae in the biological control of plant pathogenic bacteria and fungi. European. J. of Plant Pathol., 10(6): 85-599.

Mancuso S., E. Azzarello, S. Mugnai and X. Briand (2006). Marine bioactive substances (IPA extract) improve foliar ion uptake and water stress tolerance in potted Vitis vinifera plants. Adv. Hort. Sci. 20(2): 156-161.

Metting, B.; Zimmerman,W.J.; Crouch,I. and J. Van Staden (1990).Agronomic uses of seaweed and microalgae.In: Akatsuka, I. Introduction to 
Applied Phycology.pp: 589-628. SPB Academic Publishing, The Hague.

Mu8stafa, Sh. A. (2016). Effect of foliar application of Algamix and ascorbic acid on yield and quality of grape (Vitis vinifera 1.) cv. Bae-dank. Journal of University of Duhok., Vol.19, No.1 (Agri. and Vet.Sciences),Pp 403-410, 2016 (Special Issue).

Patel, G.L. and H.P. Olmo (1955). Evaluation of species and cultivars of grape. Amer. J. Bot. 42:141-159.

Ramteke, S.D and R.G. Somkumar (2005) Effect of Cycocel Sprays on Growth and Yield of Tas-AGanesh Grapes Grafted on Dogridge Rootstock. . Karnataka J. Agric. Sci., 18(1) :(18-20)

Shikhamany S.D. and Reddy, N.N. (1989). Effect of $\mathrm{CCC}$ and $\mathrm{MH}$ on petiole nutrients and leaf chlorophyll and dry matter contents in Thompson Seedless grape. India Journal of Horticulture, 16 (4): 463-467.
Smirnov, S.K. (1988), Effect of retardants on growth and fruiting of the seedless grape cultivar Kishmish Chernyi. No.V-TeeksmotogilVozdelivaniya- Vinograda, pp. 37-41.

Spinelli, F.; Fiori, G.;Noferini, M.;Sprocatti,M. and G. Costa (2009). Perspectives on the use of a seaweed extract to moderate the negative effects of alternate bearing in apple trees. J. Hort. Sci. Biotechnol.,84: 131-137.

Turan, M. and C. Kose (2004). Seaweed Extract improve Copper uptake of Grapevine. Acta Agric. Scand., Sect. B, Soil and Plant Sci. 54: 213- 220.

USAID, (2005) Agriculture reconstruction and development program for Iraq grape variety benchmarking project.

Vernieri, P.; Borghesi E.; Tognoni F.; Serra G.; Ferrante A. and Piagessi, A. (2005). Use of biostimulants for reducing nutrient solution concentration in floating system. acta Horticulture. $\quad 718, \quad 48$ 
خاندنا كارتيكرنا زناقبرنا جهقيّن ره خا ورهشاندنا بئهلجاميكس ل سهر شينبوون وداهاتيّين تريـي زةركي (Vitisvinifera L.)

ثوختة

تاقيكرنهى هاته ئهنجامدان دناف بيستانهى ترى ل كَنى دهرگهلى ل ياريّزگها دهوكي ل ههريّما كوردستانا عيراقي ل سالا 2019 زبو تاقيكرنا كارتيّكرنا زناقبرنا جهقيّن ره خا ورهشاندن بي تيراتييّن جيّاواز زئئهلجاميكس (0، 4 و 8 مل/ لتر) ل سهر شينبوون وداهاتي تريـ تاييفى. ئهنجامان دياركر كو زناقبرنا جهقيّن

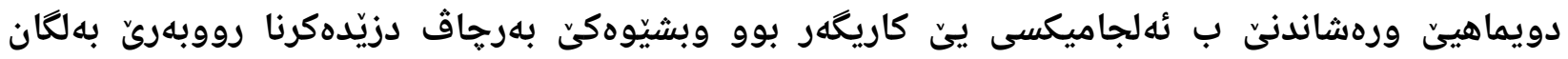
ودريّزاهيا جهقا وديسان ريّزهيا كهرهستيّن رهق ييّن ههميشهيى وداهاتي ترى يـى ههميشهيى. كارتيكرنا ليّكداني دنافبهرا فاكتهرا زى يـى كاريگهر بوو ل سهر ساخله تيّن هاتينه تاقيكرن. ليّكدان دناقبهرا زناقبرنا جهُقين ره خا ورهشاندن ب تيراتى يا بلند زئهلجاميكسى ( 8 ملا/ لتريَدا) يا باشتر بوو.

دراسة تأثير إزالة الأفرع الجانبية والرش بالألجاميكس في النمو الخضري والحاصل لكرمة العنب صنف زرك (Vitisvinifera L.)

الخلاصة

تم تنفيذ تجربة حقلية في بستان أهلي في منطقة دركلى في محافظة دهوك، اقليم كوردستان العراق خلال

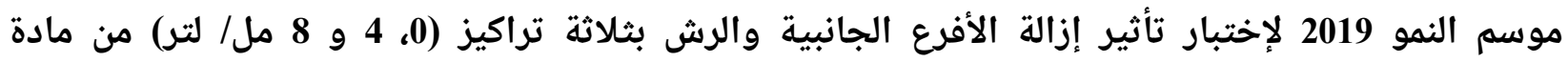
الألجاميكس والتداخل بينها في النمو الخضري والحاصل ونوعية العنب صنف زرك. أظهرت النتائج بأن ازالة

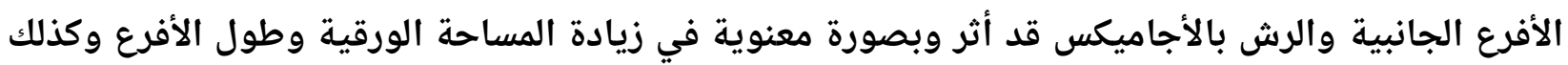
المواد الصلبة الذائبة الكلية وحاصل الكلي للكرمة. هذا وقد تباين تأثير التداخل بين العوامل المدروسة على الصفات المسجلة، حيث تبين بأن التداخل بين إزالة الأفرع الجانبية والرش بالتركيز العالي من الألجاميكس ( 8 مل/ لتر) قد كان الأفضل. 